For this form of therapy we recommend that rehydration should be done with fluids that do not contain glucose or large amounts of bicarbonate. A loading dose of 0.5 units of neutral insulin should be given followed by an infusion of neutral insulin at a rate of $40 \mathrm{mU} / \mathrm{min}(2.4$ $\mathrm{U} / \mathrm{hr}$ ) until the plasma glucose has reached a satisfactory level. Increasing the infusion rate is without additional effect, for the reasons outlined above. The infusion solution consists of $500 \mathrm{ml}$ of physiological saline containing $10 \mathrm{~g}$ of human serum albumin and 20 units of neutral insulin. This solution is used over eight hours at $60 \mathrm{ml} / \mathrm{hr}$ and is generally sufficient for completion of therapy. Plasma glucose should be measured every second hour when the previous measurement is above $300 \mathrm{mg} / 100 \mathrm{ml}$ and should be estimated hourly when below this level.

In addition to being a simple form of therapy for all degrees of hyperglycaemia and ketoacidosis low dose insulin infusion may offer a more efficient means of preparing diabetics for surgery.

This work was supported in part by grants from the National Health and Medical Research Council of Australia. We thank the medical staff and the staff of the biochemistry department of St. Vincent's Hospital for their help.

Requests for reprints should be sent to W. Kidson.

\section{References}

Alberti, K. G. M. M., Hockaday, T. D. R., and Turner, R. C. (1973). Lancet, 2, 515.

Beaser, S. B. (1970). In Diabetes Mellitus: Theory and Practice, ed. M. Ellenberg, and H. Rifkin, p. 752. New York, McGraw-Hill.

Bondy, P. K. (1971). In Cecil-Loeb Textbook of Medicine, ed. P. B. Beeson, and W. McDermott, 13th edn., p. 1651. Philadelphia, Saunders.
Bradley, R. F. (1971). In foslin's Diabetes Mellitus, ed. A. Marble, et al., 11th edn., p. 361. Philadelphia, Lea and Febiger.

Clements, R. S., jun., Prockop, L. D., and Winegrad, A. I. (1968). Lancet, 2,384

Danowski, T. S. (1970). In Diabetes Mellitus: Theory and Practice, ed. M. Ellenberg, and H. Rifkin, p. 678. New York, McGraw-Hill.

Ferrebee, J. W., et al. (1951). Endocrinology, 48, 277.

Galloway, J. A., and Shuman, C. R. (1963). American fournal of Medicine, $34,177$.

Genuth, S. M. (1973). Fournal of the American Medical Association, 223, 1348 Ginsberg, S., et al. (1973). Fournal of Clinical Endocrinology and Metabolism, 36, 1175 .

Goldner, M. G., and Clark, D. E. (1944). fournal of Clinical Endocrinology, 4, 194.

Hales, C. N., and Randle, P. J. (1963). Lancet, 1, 200.

Hepp, D., ot al. (1967). Metabolism, 16, 393

Hofman, W. S. (1937). Fournal of Biological Chemistry, 120, 51.

Lavis, V. R., and Williams, R. H. (1973). Diabetes, 22, 629

Rabinowitz, D., et al. (1972). In The Principles and Practice of Medicine, ed. A. M. Harvey, et al., 18th edn., p. 903. New York, AppletonCentury-Crofts.

Randle, P. J. (1965). In On the Nature and Treatment of Diabetes, ed. B. S. Liebel and G. A. Wrenshall, p. 361, Amsterdam, Excerpta Medica Foundation.

Sheldon, J., and Pyke, D. A. (1968). In Clinical Diabetes and its Biochemical Basis, ed. W. G. Oakley, D. A. Pyke, and K. W. Taylor, p. 436. Oxford, Blackwell.

Sonksen, P. H., et al. (1972). Lancet, 2, 155.

Steinke, J., and Thorn, G. W. (1970). In Harrison's Principles of Internal Medicine, ed. M. M. Wintrobe, et al., 6th edn., p. 535. New York, Medicine, ed.

Stern, M. P., et al. (1968). Fournal of Clinical Investigation, 47, 1947.

Turner, R. C., et al. (1971). Fournal of Clinical Endocrinology and Metabolism, 33, 279

Walker, B. G., et al. (1963). Lancet, 2, 964.

Weisenfeld, S., et al. (1968). Diabetes, 17, 766.

Williams, R. H. (editor) (1968). Textbook of Endocrinology, 4th edn., p. 746 Philadelphia, Saunders.

Williamson, J. R., and Krebs, H. A. (1961). Biochemical fournal, 80, 540.

Winegrad, A. I., and Clements, R. S., jun. (1971). Medical Clinics of North America, 55, 899.

Yalow, R. S., and Berson, S. A. (1960). Fournal of Clinical Investigation, 39, 1157.

Yalow, R. S., and Berson, S. A. (1961). American fournal of Medicine, 31, 882

Zierler, Z. L., and Rabinowitz, D. (1964). Fournal of Clinical Investigation, 43, 950 .

\title{
Continuous Intravenous Infusion of Small Doses of Insulin in Treatment of Diabetic Ketoacidosis
}

\author{
P. F. SEMPLE, C. WHITE, W. G. MANDERSON
}

British Medical fournal, 1974, 2, 694-698

\section{Summary}

Continuous intravenous infusion of small amounts of insulin has been used in the management of a series of patients with diabetic ketoacidosis. In 13 patients with a plasma glucose level on admission of $725 \mathrm{mg} / 100 \mathrm{ml}$ ( \pm 80 S.E. of mean) and an arterial pH of $7.07 \pm 0.05$ a mean loading dose of $6.5 \pm 0.82$ units of soluble insulin was administered intravenously, and thereafter a sustaining infusion of $6.5 \pm \mathbf{0 . 8 2} \mathrm{U} / \mathrm{hr}$ was continued until ketosis was corrected and the plasma glucose fell below $300 \mathrm{mg} / 100 \mathrm{ml}$. The total insulin dose needed to achieve this was $39.2 \pm 6.6$ units given over a 3 to 10 -hour period. Plasma insulin was measured in patients who had not previously received insulin and the mean level at an

The Medical Division, Glasgow Royal Infirmary Glasgow G4 OSF P. F. SEMPLE, M.B., M.R.C.P., Registrar in Medicine

(Present address: M.R.C. Blood Pressure Unit, Western Infirmary, Glasgow)

C. WHITE, M.B., M.R.C.P., Registrar in Medicine

(Present address: Department of Medicine, Manchester Royal Infirmary) W. G. MANDERSON, M.D., F.R.C.P., Consultant Physician infusion rate of $4 \mathrm{U} / \mathrm{hr}$ was $75.6 \pm 8.0 \mu \mathrm{U} / \mathrm{ml}$. Plasma glucose fell at a regular rate of $101 \pm 11 \mathrm{mg} / 100 \mathrm{ml} / \mathrm{hr}$, and ketosis improved in parallel. Plasma potassium was well maintained throughout treatment. This regimen of treatment was clinically effective and simple to follow.

\section{Introduction}

Standard treatment of diabetic ketoacidosis consists of the administration of initial doses of 50-200 units of soluble insulin with a proportion given intramuscularly or subcutaneously and the rest intravenously. In recent years the necessity and desirability of such large doses of insulin have been called into question. Frequent subcutaneous doses of 4-20 units of insulin together with small intravenous boluses have been successfully used in the management of diabetic ketoacidosis (Mohnike et al., 1971). A regimen of frequent doses of 5-10 U/hr of intramuscular insulin has recently been described by Alberti et al. (1973), who found it effective in a series of 14 patients. Good results have been reported in three ketoacidotic patients treated with continuous intravenous infusion of human monocomponent insulin in doses as low as $2.7 \mathrm{U} / \mathrm{hr}$ (Sönksen et al., 1972).

Insulin is necessary in diabetic ketoacidosis to reverse the disturbed intermediary metabolism and to correct the electrolyte imbalance in conjunction with intravenous fluid therapy. A 
progessive and predictable return to normal is more likely if insulin is supplied at a regular rate and in quantities which avoid excessive concentration.

The plasma half life of intravenous insulin is only four-five minutes (Turner et al., 1971) so that intravenous boluses need to be repeated often, and they give rise to widely fluctuating plasma insulin levels. Subcutaneous insulin has a half life of about four hours (Binder, 1969) and may be slowly and erratically absorbed in ketoacidotic patients. Tissue depots may accumulate and predispose to hypoglycaemia in the late stages of treatment. Intramuscular insulin has a duration of action between those of the intravenous and subcutaneous routes. Constant, effective, but not excessive plasma levels of insulin can be produced by continuous intravenous infusion, and we describe the use of a regimen of insulin infusion in 13 ketoacidotic and three hyperglycaemic patients.

\section{Patients and Methods}

Thirteen patients with severe uncontrolled diabetes who were admitted over a six-month period were studied. All had plasma glucose levels above $300 \mathrm{mg} / 100 \mathrm{ml}$, all had positive plasma Ketostix readings, and all needed emergency intravenous fluid therapy and prompt insulin administration. A further three hyperglycaemic, non-ketotic, and newly diagnosed diabetics were studied to ascertain plasma insulin levels achieved with continuous infusion of $0 \cdot 5-5$ units of insulin per hour.
Admission clinical details of patients are shown in table .I One patient (case 1) was hypotensive on admission and also unresponsive to painful stimuli. The patient in case 10 was also comatose, probably due to cerebral infarction rather than ketoacidosis. Clinical evidence of infection was present in five patients (cases $8,10,11,12$, and 13).

Biochemical details of the patients on admission are shown in table II. In the 13 ketoacidotic patients plasma glucose ranged from $354-1,270 \mathrm{mg} / 100 \mathrm{ml}$ (mean $725 \pm 80$ ) and arterial $\mathrm{pH}$ from 6.80-7.36 (mean 7.07 \pm 0.05 ). $\mathrm{PCO}_{2}$ ranged from unrecordable to $43 \mathrm{~mm} \mathrm{Hg}$ and base excess from $>-22-0 \mathrm{mmol} / \mathrm{l}$. Admission plasma potassium ranged from $3 \cdot 5-7 \cdot 1 \mathrm{mEq} / \mathrm{l}$. (mean $5.3 \pm 0 \cdot 3$ ), plasma sodium from $120-137 \mathrm{mEq} / \mathrm{l}$. (mean $132 \pm$ $1 \cdot 4$ ), and plasma urea from $26-187 \mathrm{mg} / 100 \mathrm{ml}$ (mean $89 \pm 14 \cdot 5$ ).

In the ketoacidotic group intravenous fluid therapy was started 15-40 minutes before the administration of insulin, and physiological saline solution $(0 \cdot 154 \mathrm{~mol} / \mathrm{l}$.) was used in all cases until plasma glucose had fallen below $300 \mathrm{mg} / 100 \mathrm{ml}$, at which time $5 \%$ dextrose was substituted. Plasma glucose was measured by a Beckman glucose analyser and plasma potassium by flame photometry. Arterial blood gas estimations were performed using the Astrup method and plasma insulin was measured by a double antibody immunoassay technique (Albano et al., 1972) using human insulin as a standard. Antibodies were obtained from the Wellcome Laboratory, Queensborough, Kent, ${ }^{125} \mathrm{I}-$ insulin from the Radio Chemical Centre, Amersham, Buckinghamshire, and insulin standards from the Biological Standards Division, National Institute for Medical Research, Mill Hill, London.

TABLE I-Clinical Details on Admission of 13 Ketoacidotic and Three Hyperglycaemic Patients

\begin{tabular}{|c|c|c|c|c|c|c|c|c|c|}
\hline Case No. & Age & Sex & $\begin{array}{c}\text { Duration } \\
\text { of } \\
\text { Diabetes } \\
\text { (Years) }\end{array}$ & $\begin{array}{c}\text { Previous Insulin } \\
\text { Treatment* } \\
\text { (U/day) }\end{array}$ & Precipitating Factor & $\begin{array}{c}\text { Blood Pressure } \\
(\mathrm{mm} \mathrm{Hg})\end{array}$ & $\begin{array}{c}\text { Pulse } \\
\text { beats/min }\end{array}$ & $\begin{array}{l}\text { Respiratory } \\
\text { Rate/min }\end{array}$ & $\begin{array}{c}\text { State of } \\
\text { Consciousness } \dagger\end{array}$ \\
\hline \multicolumn{10}{|c|}{ Ketoacidotic Patients } \\
\hline $\begin{array}{r}1 \\
2 \\
3 \\
4 \\
5 \\
6 \\
7 \\
8 \\
9 \\
10\end{array}$ & $\begin{array}{l}21 \\
36 \\
24 \\
50 \\
34 \\
55 \\
17 \\
15 \\
21 \\
67\end{array}$ & $\begin{array}{l}\text { F. } \\
\text { M. } \\
\text { F. } \\
\text { M. } \\
\text { M. } \\
\text { F. } \\
\text { F. } \\
\text { M. } \\
\text { M. } \\
\text { F. }\end{array}$ & $\begin{array}{r}4 \\
5 \\
19 \\
12 \\
8 \\
31 \\
7 \\
10 \\
13 \\
?\end{array}$ & \begin{tabular}{c|}
94 \\
52 \\
40 \\
144 \\
110 \\
32 \\
140 \\
60 \\
88 \\
Chlorpropamide \\
dose not \\
known)
\end{tabular} & $\begin{array}{l}\text { None found } \\
\text { Not taking insulin } \\
\text { None found } \\
\text { None found } \\
\text { Insufficient insulin } \\
\text { Cerebral infarct } \\
\text { None found } \\
\text { Acute bronchitis } \\
\text { None found } \\
\text { Cerebral infarct; } \\
\text { hypothermia; } \\
\text { bronchopneumonia }\end{array}$ & $\begin{array}{l}92 / 0 \\
140 / 80 \\
150 / 20 \\
105 / 60 \\
110 / 70 \\
100 / 60 \\
120 / 75 \\
125 / 90 \\
130 / 90 \\
100 / 60\end{array}$ & $\begin{array}{r}122 \\
136 \\
160 \\
120 \\
116 \\
120 \\
110 \\
120 \\
124 \\
88\end{array}$ & $\begin{array}{l}32 \\
32 \\
34 \\
30 \\
32 \\
30 \\
28 \\
22 \\
28 \\
40\end{array}$ & $\begin{array}{l}\text { Coma } \\
\text { Precoma } \\
\text { Precoma } \\
\text { Precoma } \\
\text { Precoma } \\
\text { Precoma } \\
\text { Drowsy } \\
\text { Drowsy } \\
\text { Confused } \\
\text { Coma }\end{array}$ \\
\hline 11 & 58 & F. & 10 & $\begin{array}{l}\text { (Chlorpropamide; } \\
500 \mathrm{mg} / \text { day) }\end{array}$ & $\begin{array}{l}\text { Not taking therapy; } \\
\text { Urinary infection }\end{array}$ & $124 / 78$ & 88 & 24 & Drowsy \\
\hline 12 & 66 & F. & $0 \cdot 2$ & (Chlorpropamide; & $\begin{array}{l}\text { Carcinomatosis; } \\
\text { bronchopneumonia }\end{array}$ & $130 / 70$ & 112 & 24 & Precoma \\
\hline 13 & 66 & F. & $\mathbf{0}$ & & $\begin{array}{l}\text { Cerebral infarct; } \\
\text { bronchopneumonia }\end{array}$ & $180 / 125$ & 86 & 24 & Precoma \\
\hline \multicolumn{10}{|c|}{ Hyperglycaemic Patients } \\
\hline $\begin{array}{l}14 \\
15 \\
16\end{array}$ & $\begin{array}{l}16 \\
42 \\
28\end{array}$ & $\begin{array}{l}\text { F. } \\
\text { M. } \\
\text { M. }\end{array}$ & $\begin{array}{l}0 \\
0 \\
0\end{array}$ & & & $\begin{array}{l}100 / 60 \\
122 / 78 \\
130 / 70\end{array}$ & $\begin{array}{r}100 \\
86 \\
88\end{array}$ & $\begin{array}{l}22 \\
17 \\
18\end{array}$ & $\begin{array}{l}\text { Conscious } \\
\text { Conscious } \\
\text { Conscious }\end{array}$ \\
\hline
\end{tabular}

* Total daily dose of insulin is given regardless of type used.

tPrecoma is defined as responsiveness to cain and loud noises only.

TABLB II-Biochemical Studies on Admission in 13 Ketoacidotic and Three Hyperglycaemic Patients

\begin{tabular}{|c|c|c|c|c|c|c|c|c|}
\hline Case No. & $\begin{array}{c}\begin{array}{c}\text { Plasma } \\
\text { Glucose } \\
(\mathrm{mg} / 100 \mathrm{ml})\end{array} \\
\end{array}$ & $\begin{array}{c}\text { Plasma } \\
\text { Sodium } \\
(\mathrm{mEq} / 1 .)\end{array}$ & $\begin{array}{c}\text { Plasma } \\
\text { Potassium } \\
(\mathrm{mEq} / 1 .)\end{array}$ & $\begin{array}{l}\text { Plasma Urea } \\
\text { (mg/100 ml) }\end{array}$ & $\begin{array}{c}\text { Arterial } \\
\text { pH }\end{array}$ & $\mathrm{PCO}_{2}(\mathrm{~mm} \mathrm{Hg})$ & $\begin{array}{c}\text { Base Excess } \\
(\mathrm{mmol} / 1 .)\end{array}$ & $\begin{array}{c}\text { Plasma } \\
\text { Ketostix }\end{array}$ \\
\hline \multicolumn{9}{|c|}{ Ketoacidotic Patients } \\
\hline $\begin{array}{r}1 \\
2 \\
3 \\
4 \\
5 \\
6 \\
7 \\
8 \\
9 \\
10 \\
11 \\
12 \\
13\end{array}$ & $\begin{array}{r}1,200 \\
930 \\
590 \\
1,270 \\
680 \\
686 \\
485 \\
442 \\
586 \\
822 \\
926 \\
450 \\
354\end{array}$ & $\begin{array}{l}134 \\
130 \\
130 \\
125 \\
120 \\
135 \\
130 \\
136 \\
129 \\
136 \\
137 \\
131 \\
136\end{array}$ & $\begin{array}{l}6 \cdot 4 \\
6 \cdot 5 \\
4 \cdot 5 \\
6 \cdot 4 \\
6 \cdot 1 \\
5 \cdot 0 \\
4 \cdot 7 \\
5 \cdot 4 \\
4 \cdot 8 \\
7 \cdot 1 \\
5 \cdot 0 \\
3 \cdot 8 \\
3 \cdot 5\end{array}$ & $\begin{array}{r}74 \\
96 \\
67 \\
153 \\
80 \\
80 \\
26 \\
46 \\
58 \\
184 \\
187 \\
60 \\
46\end{array}$ & $\begin{array}{l}6.80 \\
6.90 \\
6.90 \\
6.95 \\
6.93 \\
7 \cdot 02 \\
7.06 \\
7.08 \\
7 \cdot 17 \\
7 \cdot 18 \\
7 \cdot 28 \\
7 \cdot 34 \\
7 \cdot 36\end{array}$ & $\begin{array}{r}<20 \\
<20 \\
<20 \\
<20 \\
20 \\
18 \\
23 \\
27 \\
30 \\
27 \\
27 \\
43 \\
32\end{array}$ & $\begin{array}{r}>-22 \\
>-22 \\
-22 \\
-20 \\
-22 \\
>-22 \\
>-22 \\
-14 \\
-16 \\
-18 \\
-13 \\
-4 \\
0\end{array}$ & $\begin{array}{l}+++ \\
+++ \\
+++ \\
+++ \\
+++ \\
+++ \\
+++ \\
+++ \\
+++ \\
+++ \\
+ \\
+ \\
+\end{array}$ \\
\hline \multicolumn{9}{|c|}{ Hyperglycaemic Patients } \\
\hline $\begin{array}{l}14 \\
15 \\
16\end{array}$ & $\begin{array}{l}380 \\
395 \\
269\end{array}$ & $\begin{array}{l}135 \\
136 \\
138\end{array}$ & $\begin{array}{l}3.7 \\
3.9 \\
3.6\end{array}$ & $\begin{array}{l}30 \\
34 \\
36\end{array}$ & & & . & \\
\hline
\end{tabular}


The results are given as \pm S.E. of mean, and statistical significance was assessed by the $t$ test.

\section{TREATMENT}

Fluids.-Saline solution $(0 \cdot 154 \mathrm{~mol} / 1$.$) was used in the initial$ stages. A mean of $1.76 \pm 0.21$ litres was given in the first two hours with a mean of $3.3 \pm 0.3$ in the first six hours. In the first 24 hours a mean of $6.0 \pm 0.57$ litres of intravenous fluid was given to the ketoacidotic patients with a mean positive fluid balance of $3.4 \pm 0.8$ litres. No intravenous fluid was given to the hyperglycaemic patients (cases 14,15, and 16).

Potassium.-Intravenous potassium was started on admission only if the plasma potassium was below $5.0 \mathrm{mEq} / \mathrm{l}$. Thereafter potassium was given as soon as the plasma potassium fell below $5.0 \mathrm{mEq} / \mathrm{l}$. In the first four hours of treatment $20 \pm$ $3.2 \mathrm{mEq}$ was given, in the first six hours $42.5 \pm 7.5 \mathrm{mEq}$, and in the first 24 hours $122 \pm 13.7 \mathrm{mEq}$. The doses over the 24 -hour period ranged from nil in case 10 , a patient who had renal failure, to $210 \mathrm{mEq}$ in the patient in case 1 , who was the most severely ketotic patient in the series.

Bicarbonate. - The use of bicarbonate was restricted to four of the patients with an arterial $\mathrm{pH}$ of less than $7 \cdot 0$ (cases 1 , 3,4 , and 5) and one further patient with a $\mathrm{pH}$ of 7.02 who was hypotensive (case 6). Single doses not exceeding $100 \mathrm{mEq}$ were given in $0.5 \mathrm{l}$. physiological saline $(0.154 \mathrm{~mol} / \mathrm{l}$.) over 30 minutes together with $20 \mathrm{mEq}$ potassium chloride. The mean dose given to the five patients was $77 \pm 11.8 \mathrm{mEq}$.

Insulin.-Insulin therapy was started in all patients between 15 minutes and 40 minutes after admission to hospital. Twohundred units of soluble insulin were drawn into a $50-\mathrm{ml}$ syringe and diluted up to $50 \mathrm{ml}$ with saline $(0.154 \mathrm{~mol} / \mathrm{l}$. M) containing $1 \mathrm{~g}$ salt-poor human albumin/100 ml (Scottish National Blood Transfusion Association, Edinburgh). Albumin was necessary to reduce adsorption of insulin to the infusion apparatus (Sönksen et al., 1965). A loading dose of 2-12 units of soluble insulin was given intravenously and a continuous infusion of the insulin solution was then started using a syringe pump (Sage, model 240, Dylade Co. Ltd., Runcorn, Cheshire). The syringe was connected to the patient's intravenous infusion via a manometer connecting tube and a standard $\mathrm{Y}$ connector. Insulin was thereafter given at a rate of $2-12 \mathrm{U} / \mathrm{hr}$ and the infusion was continued until ketosis was corrected. Ketosis was considered to be corrected when hyperventilation had ceased, plasma Ketostix gave negative readings, and plasma $\mathrm{pH}$ was greater than 7.34 One patient received 2 units as a priming dose and thereafter 2 $\mathrm{U} / \mathrm{hr}$ (case 8 ), six patients received 4 units followed by $4 \mathrm{U} / \mathrm{hr}$ (cases $2,7,10,11,12$, and 13), four patients received 8 units followed by $8 \mathrm{U} / \mathrm{hr}$ (cases $1,3,4$, and 6 ), and two patients received 12 units followed by $12 \mathrm{U} / \mathrm{hr}$ (cases 5 and 9). The first patients admitted to the study were treated with $12 \mathrm{U} / \mathrm{hr}$ to establish the efficacy of the regimen. Subsequent patients were treated with lower doses of insulin, the major factor determining the dose being the severity of the patient's illness. When ketosis was corrected and the plasma glucose fell below $300 \mathrm{mg} / 100 \mathrm{ml}$ the rate of infusion was either reduced to a maintenance level of between $0 \cdot 5-2 \mathrm{U} / \mathrm{hr}$ for a further 6-12 hours, depending on plasma glucose levels, or subcutaneous insulin was started on a sliding scale determined by urine tests. A mean dose of $39 \cdot 2 \pm$ 6.6 units was given between the time of admission and control of the ketosis, and the mean time taken to achieve control was $6.4 \pm 0.9$ hours (range 2-10). The three hyperglycaemic patients received slowly increasing doses of insulin from $0.5 \mathrm{U} / \mathrm{hr}$ to 5 $\mathrm{U} / \mathrm{hr}$ with measurements of plasma insulin at each rate of infusion.

\section{Results}

Glucose.-On treatment with insulin and intravenous fluids there was an exponential fall in plasma glucose (see fig.). The mean rate of fall of plasma glucose was $101 \pm 11 \mathrm{mg} / 100 \mathrm{ml} / \mathrm{hr}$ until intravenous dextrose was begun. In each patient the plasma glucose fell after one hour of therapy and this result was statistically significant by paired $t$ test $(P<0.001)$. The relatively faster rate of fall in the first hour was probably due to haemodilution. The rate of fall was relatively predictable in any patient and there were no late hypoglycaemic episodes. It was never necessary to increase the original rate of insulin infusion. The mean rate of fall of plasma glucose for the six patients receiving 8-12 $\mathrm{U} / \mathrm{hr}$ was $114 \pm 7 \mathrm{mg} / 100 \mathrm{ml} / \mathrm{hr}$ and for the seven patients receiving $2-4 \mathrm{U} / \mathrm{hr} 88 \cdot 8 \pm 21 \mathrm{mg} / 100 \mathrm{ml} / \mathrm{hr}$. This difference was is not statistically significant by Student's $t$ test.

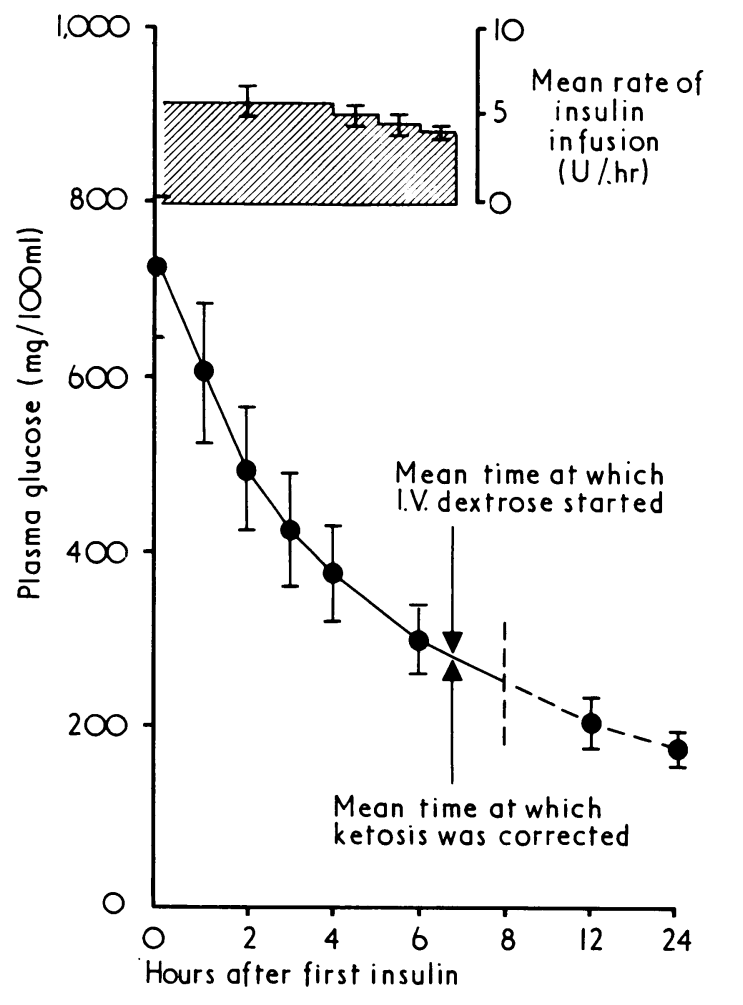

Mean plasma glucose in 13 ketoacidotic patients treated with low dose continuous infusion of insulin. Mean rate of insulin in the first 6.4 hours of infusion is also shown but priming dose is not represented.

Ketosis.-The response of ketosis to treatment was followed by plasma Ketostix (Ames) measurements at 1, 2, 3, 4, 6, 12, and 24 hours after the beginning of treatment. Negative Ketostix readings with normal ventilation pattern and blood $\mathrm{pH}$ were found in all subjects at a mean of $6.4 \pm 0.9$ hours after the start of insulin therapy (see fig.).

Changes in Plasma Potassium.-Plasma potassium levels were well maintained throughout treatment. In only one patient did the value fall below $3.5 \mathrm{mEq} / \mathrm{l}$. and this was on one occasion at six hours (case 8 ). Values at $1,2,3,4,6$, and 12 hours respectively were $4.6 \pm 0.35 \mathrm{mEq}, 4.4 \pm 0.28 \mathrm{mEq}, 4.5 \pm 0.30 \mathrm{mEq}, 4.6$ $\pm 0.32 \mathrm{mEq}, 4.4 \pm 0.14 \mathrm{mEq}$, and $4.6 \pm 0.10 \mathrm{mEq} / 1$

Effect of Insulin Infusion on Plasma Insulin.-Plasma insulin was measured in three of the ketoacidotic patients treated with 4 units of insulin per hour who had not previously received insulin (cases 10,11, and 12). In two of these patients further plasma insulin measurements were made at lower rates of infusion after ketosis had been corrected. The results are shown in table III. Increments in plasma insulin over pretreatment levels of between 44 and $106 \mu \mathrm{U} / \mathrm{ml}$ were observed. The three hyperglycaemia patients also had measurements of plasma insulin over 30 -minute periods at increasing insulin infusion rates. One to three measurements were made in each patient 
TABLE III-Increments in Plasma Insulin Produced by Continuous Infusion of Insulin in Six Patients. Results are expressed as $\mu U / m l( \pm$ S.E. of Mean when three or more Observations were made)

\begin{tabular}{|c|c|c|c|c|c|c|c|c|}
\hline \multirow{3}{*}{ Case No. } & \multicolumn{8}{|c|}{ Rate of Insulin Infusion (U/hr) } \\
\hline & & & & 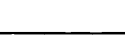 & & & & \\
\hline & 0.5 & 1 & 2 & $2 \cdot 5$ & 3 & & 4 & 5 \\
\hline \multicolumn{9}{|c|}{ Ketoacidotic Patients. } \\
\hline $\begin{array}{l}10 \\
11 \\
12\end{array}$ & $1 \pm 0 \cdot 2$ & $9 \pm 0.2$ & & $\begin{array}{l}34 \pm 5.5 \\
31 \pm 2.6\end{array}$ & 45 & $\begin{array}{l}62 \\
88 \\
58 \cdot 7\end{array}$ & $\begin{array}{l} \pm 7 \cdot 1 \\
\pm \quad 8 \cdot 2 \\
\pm 5 \cdot 0\end{array}$ & \\
\hline \multicolumn{9}{|c|}{ Hyperglycaemic Patiertss } \\
\hline $\begin{array}{l}14 \\
15 \\
16\end{array}$ & $2 \cdot 5$ & $\begin{array}{c}7.5 \\
18.2 \pm 3.4 \\
15.5 \pm 6.5\end{array}$ & $\begin{array}{l}33 \pm 4 \cdot 7 \\
28 \pm 2 \cdot 3\end{array}$ & $13 \cdot 5$ & & & & 80 \\
\hline
\end{tabular}

during each of the infusion periods and, the results are also shown in table III. An appropriate priming dose was given at the beginning of each infusion period. The observed increments in plasma insulin were proportional to the rate of insulin infusion, and plasma glucose fell in each individual in a linear manner at infusion rates of $1 \mathrm{U} / \mathrm{hr}$ and above (mean rate of fall of plasma glucose $115 \pm 5 \mathrm{mg} / 100 \mathrm{ml} / \mathrm{hr}$.

Morbidity and Mortality.-Two patients died after correction of ketoacidosis. At necropsy the patient in case 10 had a large cerebral infarct, bronchopneumonia, and thrombus in both atria, and the patient in case 12 had carcinomatosis and bronchopneumonia.

\section{Discussion}

Continuous intravenous infusion of small doses of insulin is in our experience effective in the treatment of diabetic ketoacidosis even in the most severe cases (case 1). For many years the standard policy for treatment of this condition has been to give large and frequent doses of insulin (Hudson et al., 1960; Krall, 1963; Cohen et al., 1960; Smith and Martin, 1954; Soler et al., 1973), and retrospective studies (Soler et al., 1973; Black and Malins, 1949; Root, 1945) have shown that such treatment is effective. The use of large doses of insulin has recently been questioned, and the successful treatment of diabetic ketoacidosis with small frequent subcutaneous and intravenous doses (Mohnike et al., 1971) and intramuscular doses (Alberti et al., 1973) has been described. Alberti et al. have found a progressive fall in blood lactate during therapy, in contrast to previously noted observations of a rise during conventional management (Alberti and Hockaday, 1972), and they have also noted an improvement in the maintenance of plasma potassium levels. It seems to us that the logical method of giving insulin is by continuous intravenous infusion, which produces constant effective plasma levels of insulin, avoids the vagaries of absorption from tissue depots, and overcomes the problem of the short half life of intravenous insulin. Insulin is non-specifically adsorbed to glass and other surfaces (Ferrebee et al., 1951; Hill, 1959; Newerly and Berson, 1957), and in this study it was given in a $1 \%$ solution of human albumin, which is a known competitive inhibitor of insulin adsorption (Sönksen et al., 1965). Continuous intravenous infusion of large doses of insulin (30-100 $\mathrm{U} / \mathrm{hr}$ ) in the management of diabetic ketoacidosis has previously been reported (Rossier et al., 1960; Gesuth, 1973). The successful use of a low-dose regimen has been described in the treatment of three ketoacidotic patients by Sönksen et al. (1972), who infused human monocomponent insulin in a $1 \%$ solution of human albumin. The most severely affected patient described responded to a total dose of 34 units of insulin infused over a period of seven hours. The rate of fall of plasma glucose noted in the two series using high doses of insulin was similar to the rate observed in this study, and this may be explained by saturation of the insulin receptors which mediate glucose transport.

Our results show that a priming dose of 2-12 units of soluble insulin intravenously followed by 2-12 units of insulin per hour administered in a $1 \%$ solution of human albumin by syringe pump produced a progressive and smooth response of plasma glucose and ketoacidosis to treatment. This regimen has been successful in all cases to date and it has not been necessary to increase the initial rate of insulin infusion. The mean rate of fall of plasma glucose was lower in the patients infused with 2-4 $\mathrm{U} / \mathrm{hr}$ compared to the patients who received 8-12 $\mathrm{U} / \mathrm{hr}$ but this difference was not statistically significant. The two groups of patients were not strictly comparable; the low dose group included the patients who had not received insulin before and those with evidence of infection. The mean plasma insulin attained with $4 \mathrm{U} / \mathrm{hr}$ was $75.6 \pm 8.0 \mu \mathrm{U} / \mathrm{ml}$, and this is within the range of $20-200 \mu \mathrm{U} / \mathrm{ml}$ at which insulin has a maximal effect on glucose transport in normal subjects (Sönksen et al., 1972). Plasma potassium was well maintained throughout treatment but this might have reflected vigorous replacement of deficits and sparing use of bicarbonate.

This insulin regimen used in this study has a number of advantages compared with other forms of treatment. It is simple to administer compared with frequent injections, and it produced a progressive and predictable rate of recovery in individual patients. The rate of insulin infusion is readily controlled compared to the administration of insulin in the drip bottle. The human albumin solution used is free of $\mathrm{HB}$ antigen and the risk of introducing infection is negligible. The only disadvantage is the need for a syringe pump; these are, however, relatively inexpensive and have many other uses in an acute receiving area.

The use of continuous intravenous infusion of insulin in the management of diabetic ketoacidosis is a logical advance in treatment. We recommend that patients who are severely ill receive a priming dose of 8 units of soluble insulin followed by an infusion of $8 \mathrm{U} / \mathrm{hr}$. An infusion rate of $4 \mathrm{U} / \mathrm{hr}$ after a priming dose of 4 units may well be as effective as the higher dose, but until we have more experience of the technique we suggest that this lower dose regimen be reserved for patients who are less seriously ill.

We thank the physicians of Glasgow Royal Infirmary for permission to study and publish details of patients under their care, Dr. J. Ratcliffe for the insulin assays, and the department of clinical biochemistry.

\section{References}

Albano, J. D. M., Ekins, R. P., Maritz, G., and Turner, R. C. (1972). Acta Endocrinologica (Kóbenhavn), 70, 487

Alberti, K. G. M. M., and Hockaday, T. D. R. (1972). Diabetes, 21, Suppl. 1 350.

Alberti, K. G. M. M., Hockaday, T. D. R., and Turner, R. C. (1973). Lancet, 2,515 .

Binder, C. (1969). Absorption of Injected Insulin. Copenhagen, Munksgaard. Black, A. B., and Malins, J. M. (1949). Lancet, 1, 56.

Cohen, A. S., Vance, V. K., Runyan, J. W., and Hurwitz, D. (1960). Annals of Internal Medicine, 52, 55.

Ferrebee, J. W., Johnson, B. B., Mithoefer, J. C., and Gardella, J. W. (1951) Endocrinology, 48, 277.

Gesuth, S. M. (1973). Fournal of the American Medical Association, 223, 1348 Hill, J. B. (1959). Endocrinology, 65, 515.

Hudson, B., Bick, M., and Martin, F. I. R. (1960). Australasian Annals of Mudson, B., Bick, $M$.
Medicine, $9,34$.

Medicine, 9, 34.
Krall, L. P. (1963). Fournal Lancet, 83, 347.

Mohnike, G., Wappler, E., and Bibergeil, H. (1971). In Handbuch des Diabetes Mellitus, ed. E. Pfeiffer, vol. 2, p. 1121. Munich, Lehmanns. Newerly, K., and Berson, S. A. (1957). Proceedings of the Society for Experimental Biology and Medicine, 94, 751. 


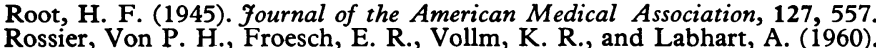
Schweizerische Medizinische Wochenschrift, 90,952

Smith, K., and Martin, J. E., (1954). Diabetes, 3, 287.

Soler, N. G., Bennett, M. A., Fitzgerald, M. G., and Malins, J. M. (1973). Lancet, 1, 951.
Sönksen, P. H., Ellis, J. P., Lowy, G., Rutherford, A., and Nabarro, J. D. N. (1965). Diabetologia, 1, 208

Sönksen, P. H., Srivastava, M. C., Tompkins, C. V., and Nabarro, J. D. N. (1972). Lancet, 2, 155.

Turner, R. C., Grayburn, J. A., Newman, G. B., and Nabarro, J. D. N. (1971). Fournal of Clinical Endocrinology and Metabolism, 33, 279.

\title{
Measurement of Side Effects of Drugs
}

\author{
E. C. HUSKISSON, J. A. WOJTULEWSKI
}

British Medical fournal, 1974, 2, 698-699

\section{Summary}

In a clinical trial of two antirheumatic agents two methods of collection of side effects were used, one with and the other without a check list of possible symptoms. Findings suggested that the use of a check list interfered with the collection of side effects. Known side effects of aspirin-tinnitus, deafness, and gastrointestinal disturbance-were more efficiently shown and symptoms not included in the check list were more likely to be reported when a check list was not used.

\section{Introduction}

Though considerable importance now attaches to the early recognition of drug toxicity the amount of research effort devoted to methods of detection of adverse effects of drugs is very small in comparison with that spent on measurement of effectiveness. The insistence by some authorities that a check list should be used to remind patients taking part in clinical trials of symptoms they might be having is presumably based on domestic principles; the housewife can hardly be expected to remember her household requirements without a shopping list. It is well known to a grocer that if his wares are displayed they are more likely to be bought. The same is true of side effects. Greenblatt (1964) showed that side effects were about five times more frequent if a check list was used. The housewife knows, however, that a display of wares in the supermarket is not always desirable; she may select more goods but forget some that she needed. The possibility that the same could be true of side effects prompted this investigation.

\section{Methods}

A study of methods of collection of side effects was made as part of a six-month assessment of two analgesic antiinflammatory drugs, aspirin and fenoprofen, the results of which were reported by Huskisson et al. (1974). Sixty patients with rheumatoid arthritis at two centres received either aspirin or fenoprofen according to a randomized schedule. At one centre patients were simply asked the following question: "Have you noticed any new symptoms which might be related to the treatment?" At the other centre a check list was also used comprising a list of 21 possible side effects including tinnitus, deafness, and a

St. Bartholomew's Hospital, London EC1 7BE

E. C. HUSKISSON, M.B., M.R.C.P., Senior Registrar

Westminster Hospital, London SW1

J. A. WOJTULEWSKI, M.B., M.R.C.P., Senior Research Registrar variety of gastrointestinal complaints as well as a number of side effects with no obvious relevance. Each side effect was recorded as absent, slight, moderate, or severe and assigned values of $0,1,2$, or 3 respectively; from the sum of the values obtained a side effect score was calculated.

\section{Results}

Auditory and gastrointestinal side effects were significantly commoner on aspirin than on fenoprofen. The remainder of the side effects elicited occurred with equal frequency on both drugs and were called "irrelevant." These three groups are shown in table I according to whether or not a check list was used. The group in which no check list was used proved to be more efficient in detecting the two significant groups of side effects. For both auditory and gastrointestinal side effects the incidence on fenoprofen was at least twice as great when a check list was used, and the incidence on aspirin was not correspondingly greater. Thus the difference between the incidence of the significant side effect and the "background" incidence in the control population was diminished. This was particularly apparent for gastrointestinal disturbances, which presumably reflected the frequent occurrence of such symptoms unrelated to treatment.

Irrelevant side effects were much commoner when a check list was used (see table I). It could be argued that a check list should be used so that the occasional totally unexpected side effect will be reported. That this is not so is shown in table II. While side effects which appeared on the check list (solicited side effects) were much more frequently reported when a check list was used, unsolicited side effects (those which did not appear on the check list) were more likely to be volunteered when a check list was not used. A check list did not much increase the rate of appearance of side effects (see fig.)

TABLE I-Side Effect Scores (\%) *for Three Groups of Side Effects, collected either in Response to Simple Question or with Check List of possible Symptoms

\begin{tabular}{|c|c|c|c|}
\hline \multirow{2}{*}{ Side Effect } & \multirow{2}{*}{ Treatment } & \multicolumn{2}{|c|}{ Side Effect Score (\%) } \\
\hline & & Check List & No Check List \\
\hline Deafness and tinnitus & $\begin{array}{l}\text { Aspirin } \\
\text { Fenoprofen }\end{array}$ & 111 & $\begin{aligned} 91 \\
3\end{aligned}$ \\
\hline Gastrointestinal & $\begin{array}{l}\text { Aspirin } \\
\text { Fenoprofen }\end{array}$ & $\begin{array}{l}93 \\
54\end{array}$ & $\begin{array}{r}134 \\
26\end{array}$ \\
\hline ..Irrelevant".. & $\begin{array}{l}\text { Aspirin } \\
\text { Fenoprofen }\end{array}$ & $\begin{array}{l}143 \\
130\end{array}$ & $\begin{array}{l}87 \\
68\end{array}$ \\
\hline
\end{tabular}

*Side effect score (\%) w?s calculated by multiplying total side effect score for each patient by 100 and dividing by number of patients

TABLE II-Side Effect Scores (\%) according to whether Side Effects were included on Check List (Solicited) or not (Unsolicited)

\begin{tabular}{l|c|c}
\hline \multirow{2}{*}{ Side Effects } & \multicolumn{2}{|c}{ Side Effect Score \% } \\
\cline { 2 - 3 } & Check List & No Check List \\
\hline Solicited & 239 & 126 \\
\hline Unsolicited & 33 & 65 \\
\hline
\end{tabular}

